\title{
EMERGENCE OF NIPAH VIRUS: A REVIEW
}

\section{Rama Adiga}

Division of Bioinformatics and Computational Genomics, Nitte University Centre for Science Education and Research (NUCSER), Nitte Univsersity, Paneer Campus, Mangalore, India - 5750018

Article Info: Received 28 January 2019; Accepted 20 February. 2019

Cite this article as: Adiga, R. (2019). - EMERGENCE OF NIPAH VIRUS: A REVIEW. Journal of Biomedical and Pharmaceutical Research, 8(1).

DOI: https://doi.org/10.32553/jbpr.v8i1.576

Address for Correspondence: Rama Adiga, Nitte Univsersity, Paneer Campus, Mangalore, India Conflict of interest statement: No conflict of interest

\section{ABSTRACT:}

An emerging zoonotic infection caused by Nipah virus has become a Biosafety Level-4 pathogen capable of causing infection in animals and man. Bats belonging to Pteropodidae family, genus Pteropus which constitute fruit bats are the host reservoirs. Genus Eidolon constituting nonpteropid bats were later found to contain the virus. Genetic and molecular similarities between Nipah and Hendra viruses helped their classification into a new genus of Henipavirus.The first reported outbreak of Nipah disease from Malaysia took place in 1998.Two genetic strains of Nipah have been identified in Asia which are of severe and less severe forms. Surveillance should be upgraded and more research focussing on Nipah were envisaged in the blueprint published by WHO.

\section{INTRODUCTION}

\section{ETIOLOGICAL AGENT}

The etiologic agent held responsible for the respiratory illness and causing encephalitis in human in Malaysia during the period 1988-89 was found to be Nipah virus. Transmission of Nipah virus occurs from infected pigs, bats, or contaminated food (Uppal et al. 2000, Lam et al. 2002). Transmission in human has also been reported through nosocomial infection (Tan and Tan 2001, Luby et al. 2012). Fruits such as raw dates and date palm juice were found to be the source of outbreaks in Bangladesh and India. Palm sap becomes contaminated as a result of bats feeding on them which gets transmitted to human during consumption of sap was presumed to be the reason. Workers climbing date palm trees also caught infection (Luby et al. 2012; Montgomery et al. 2008). However, transmission in human was reported during subsequent outbreaks in Bangladesh and India through hospital staff and visitors of patients (Chadha et al. 2006; Gurley et al. 2007).

\section{EPIDEMIOLOGY}

\section{The emergence of Nipah in Malaysia:}

In the year 1998-1999 in a major outbreak, to stop further transmission many pigs were culled. The approximate number of pigs culled went up to 1.1 million. 105 of the 257 reported human cases were fatal and were highly contagious with symptoms of febrile encephalitis and respiratory involvement; sometimes affecting nervous system. Encephalitis was more common than respiratory symptoms; sometimes followed by coma (Chua et al. 1999; Goh et al. 2000; Sherrini et al. 2014).Those who survived from the infection had nervous episodes. In all these cases, there was direct human contact with 
pigs since they were all employed in pig farms or abbatoirs (Parashar et al. 2000). In 1999, Center for Disease Control and Prevention (CDC) located in Atlanta described a hitherto unreported virus probably belonging to family Paramyxoviridae as reported by CDC (CDC 1999, Chua et al. 1999). Further investigations describing the virus, named it Nipah and found it was closely related to Hendra virus (Chua et al. 2000; Harcourt et al. 2000; Wang et al. 2000). Nipah virus infection has also been found to be susceptible to dogs, pigs and cats and later was isolated from farms (Chua et al. 2000). Nipah Virus was isolated from bats of Pteropodidae family but there was no reactivity with $A b^{\prime} s$ of anti-Nipah virus indicating lack of disease in bats (Chua et al. 2002).

Movement of swine and pig was the primary mode of spread in the region via the nasal route. The outbreak started in Perak, northern Malaysia and spread rapidly because of panic selling of pigs. Inter transfer between farms may also have introduced the virus into new communities.

South Asia became endemic to the virus and outbreaks were reported sporadically in Singapore, Malaysia, India and Bangladesh. Though the number of cases per year was dwindling worldwide a surveillance strategy was lacking.

Hsu et al reported extensive outbreak investigations of deaths related to Nipah virus in Meherpur in 2001 and Naogaon in 2004 both in Bangladesh (Hsu et al. 2004; WHO report 2012).In 2001 Siliguri, West Bengal, India reported symptoms of febrile encephalitis and were similar to Nipah of Bangladesh in epidemiology. In the period 2001-2008 the focal point of Nipah infection remained in Bangladesh, reporting human-tohuman transmission perhaps through nosocomial infection.

\section{Outbreak in Philippines affecting human in 2014:}

In Mindanao village of South Philippines an outbreak occurred in 2014, involving horses which transmitted the virus into humans infecting 17 people. The infected people either worked at slaughter houses or consumed meat or were involved in patient care. However, death of horses was reported while some horses contracted neurological disease (Ching et al. 2015).

South Asia is endemic to the disease with sporadic occurrences reported from Singapore, Malaysia, Bangladesh and India. There is a lack of surveillance but about 20 cases are still reported annually. Surveillance of Nipah virus using phylogenetic analysis may help in epidemiological studies. Preventive strategy is also dependent on understanding the origin of the virus and designing of effective vaccines and therapies.

\section{Origin of Nipah:}

The origin of the virus may be traced to Kampung Sungai Nipah, a village situated by the banks of the river Nipah in Malaysia (Lee et al. 1999; Centers for Disease Control and Prevention, 1999). The natural host reservoir of Nipah viruses were Pteropus bats (Nowak 1994)..

\section{The putative natural host:}

The natural host reservoir of Nipah were fruit bats belonging to genus Pteropus (Johara et al. 2001).The bat species occur in great diversity in Malaysia. Five species of bats which include four species of fruit bats were prevalent in Malaysia. 58 species of flying foxes were natural hosts of the virus which extend from African east coast to S.E Asia, across Philippines and Pacific, up to Australia. The three species of Pteropus identified in Cambodia included $P$. lylei, $P$. vampyrus and $P$. Iylei, out of which $P$. Iylei had shown the presence of antibodies . 
Rama Adiga, Journal of Biomedical and Pharmaceutical Research

\section{TRANSMISSION MECHANISMS}

Bats were the reservoirs for the virus since 1950's.After the year 2000 the bat population started dwindling and the dynamics of infection increased. The infection spiltover into dogs, pigs and monkeys over a period of time lead to mutation which brought about evolution in the virus. The infection of Nipah virus in bats became widespread without causing disease in the host suggesting that bats act as reservoir. Some authors hypothesized that with environmental changes like deforestation, which reduced the bat population, may probably have led to humanto-human transmission (Chua et al. 2002). Though Pteropus bats carry the infection but do not suffer from it the role of bats as reservoirs is suggested.

There were two mechanisms for the introduction of Nipah virus into human population. Transmission from flying foxes to human through an intermediate animal host. This type was seen in outbreaks from Malaysia. In Malaysia, the animal host was generally infected pigs. Transmission was by handling of infected pigs or secretions therefrom. Pigs to human transmission was the major cause. The other mechanism was transmission from bats to human as found in the outbreaks of India and Bangladesh.

Nipah virus isolates from Bangladesh and Malaysia form two distinct strains genetically Bangladesh strain and Malaysian strain (Harcourt et al. 2005). In the Bangladesh strain, the severity of disease was greater with acute respiratory disease in infected people than in Malaysian strain. In Malaysia however, there was no evidence of human transmission (Parashar et al. 2000). The number of cases due to Nipah reported worldwide was more than 600 with fatality rates of $100 \%$ for some outbreaks.

Nipah viruses and its closely related species comprising, Henipaviruses occur all over world ranging from Australia to Asia and Africa in Pteropus bats and non-Pteropid, Eidolon helvum species of fruit bats (Eaton et al. 2007; Hayman et al. 2008). In the densely populated area of human dwelling, near bat habitat the sporadic spillover or even occasional spillover of virus to human results in increase in human infection. Spread of Hendra virus from bats to horses had led to fatality in all the occasions. The effects and consequences of Nipah virus spread in terms of public health have been more severe than Hendra virus. Over 100 people died in 1998 in Malaysia and Singapore (CDC 1999). Till 2016, more than 140 people died in India and Bangladesh in 10 outbreaks (Wacharapluesadee et al. 2016). There was a clear evidence of spread by human transmission and raising the possibility of a human epidemic.

\section{Indian culture:}

The sap from date palm trees (Phoenix sylvestris) are tapped to collect the sap into clay pots and overnight collection of sweet sap is retrieved and drunk early in the morning. However, these sap are also consumed by Pteropus bats especially during winter when other fruits are not available. Date palm sap collection is rooted in Bengali culture and would be difficult to remove.

\section{NIPAH STRUCTURAL ASSEMBLY}

Nipah virus transcription and replication enzyme activities are thought to be controlled by $L$ protein subunit. It is a viral RNA dependant RNA polymerase showing similarity to other negative sense RNA viruses. Six conserved domains have been identified,each having concatenated. variable regions. The other major structural proteins of importance are nucleocapsid $(N)$, phosphoprotein $(P)$, matrix protein $(M)$, fusion protein $(F)$ and glycoprotein (G) (Wang et al. 2001).The phosphoprotein $(P)$ is important as a cofactor of polymerase helping in processing and encapsidation of viral genomes. $\mathrm{P}$ protein 
helps to connect between polymerase and its template and has a role in chaperoning $\mathrm{N}$ protein. An additional role for $P$ is in immunosuppression blocking signalling of STAT1.

Assembly of Nipah virus is similar to Sendai virus having an $\mathrm{N}$-terminal capping region involved in interactions. But Nipah virus structure has more coiled coils than Sendai typical of hydrophobic interactions.

Analysis of protein-protein interaction between Nipah virus and host assemblies was carried out. The functional categories of proteins of Nipah virus associated with host proteins were identified. The $F$ protein of
Nipah was associated with endoplasmic reticulum, the $G$ protein associated with the Ephrin receptor pathway. The $C$ protein of Nipah virus has a role in shuttling between nucleus and cytoplasm in inhibiting antiviral machinery. The $\mathrm{W}$ proteins are involved in inhibition of toll like receptors of signal transduction pathway. The $M$ proteins or matrix protein are associated with ubiquitin ligase and inhibit antiviral response (Bharaj et al. 2016, Gil et al. 2017).The PRP19 in a complex was associated with $\mathrm{V}, \mathrm{W}$ and $\mathrm{P}$ proteins and the RNAi interactor list of proteins. The PRP19 has been implied as having a role in cellular antiviral response (Gil et al. 2017).

\begin{tabular}{|l|l|l|l|l|l|l|l|l|}
\hline CELLULAR COMPONENTS & N & P & V & W & C & M & F & G \\
\hline NADH Dehydrogenase complex & & & & & & & & \\
\hline PRP19 complex & & & & & & & & \\
\hline Nuclear Pore & & & & & & & & \\
\hline Microbody membrane & & & & & & & & \\
\hline Vacuole & & & & & & & & \\
\hline Nuclear periphery & & & & & & & & \\
\hline RNAi effector complex & & & & & & & & \\
\hline Ubiquitin ligase complex & & & & & & & & \\
\hline ER part & & & & & & & & \\
\hline Proteosome complex & & & & & & & & \\
\hline BIOLOGICAL PROCESS & & & & & & & & \\
\hline Estrogen Biosynthetic process & & & & & & & & \\
\hline RNA processing & & & & & & & & \\
\hline RNA splicing & & & & & & & & \\
\hline Regulation ofcell cycle & & & & & & & & \\
\hline Nuclear localization & & & & & & & & \\
\hline Membrane organization & & & & & & & & \\
\hline Regulation of transport & & & & & & & & \\
\hline Ubiqutinization & & & & & & & & \\
\hline Peroxisomal transport & & & & & & & & \\
\hline RNA interference & & & & & & & & \\
\hline Membrane localization & & & & & & & & \\
\hline ER stress response & & & & & & & & \\
\hline Endothelial cell migration & & & & & & & & \\
\hline Lymphocyte costimulation & & & & & & & & \\
\hline Ephrin signaling pathway & & & & & & & & \\
\hline & & & & & & & & \\
\hline
\end{tabular}

Figure 1: Heat maps showing cellular components and processes based on interaction of Nipah virus proteins with human proteins 
Rama Adiga, Journal of Biomedical and Pharmaceutical Research

(Adapted from Gil et al, 2017) Dark shaded column showing maximum expression of protein.

\section{WHO BLUEPRINT:}

The WHO conducted a review in 2018 for prioritization of diseases which are infectious to human health. Since there is a potential hazard to health of public and the complete lack of drugs and vaccines which are effective in the case of virus outbreak, R\&D activity has been focused and has been accelerated in the area of Nipah research and included it in the priority list.

\section{LABORATORY DIAGNOSIS}

Diagnosis of Nipah virus can be done by histopathology, virus isolation, immunohistochemistry, molecular and serological tests. Though the gold standard is virus isolation, it can be cultured in vero cells producing cytotoxicity in 3 days. During acute phase nasal or throat swabs, urine or blood samples are used for Nipah isolation. Tissue samples from spleen, lungs and kidneys are used to test for virus in animals. ELISA can be used for convalescent phase testing and do not require BSL-4 labs for diagnosis. Molecular tests are very sensitive and specific for identification of Nipah virus. The genes for protein $\mathrm{M}, \mathrm{N}$ and $\mathrm{P}$ are used during outbreaks.

\section{RECENT OUTBREAK IN INDIA}

The outbreak in Kerala, India with a high fatality rate occurred after eleven years indicating lack of preparedness. 23 cases of Nipah were detected from $2^{\text {nd }}$ to $29^{\text {th }}$ May, 2018 out of which 18 were confirmed cases and 4 were suspected cases. Transmission of Nipah virus was reported in three hospitals of Kozhikkode district with taluk level headquarters at Perambra, Kozhikkode and PHC at Balussery. Queensland health department of Australia on special grounds donated 50 doses of vaccine (MAb's) against a related virus, Hendra virus which was stored at
Kozhikode government college hospital (Kumar \& Kumar, 2018).

\section{CONCLUSION}

The recent outbreak in Kerala, India was an eye opener to the unpreparedness of virus spread caused by Nipah. Sensitization at administration level of all countries is desirable in the wake of frequent episodes of viral outbreaks over vast geographical areas. The development of vaccines specific for Nipah virus should be taken up by scientific bodies and research and surveillance activities enhanced.

Conflict of interest statement: There is no conflict of interest reported

\section{ACKNOWLEDGEMENTS}

The author wishes to thank Indrani Karunasagar, Director (R\&D), Nitte University Centre for Science Education and Research and the Management of Nitte University, Deralakatte, Mangalore, Karnataka, India for the support in establishing the centre, providing facilities and continuous encouragement in research, including the present work.

\section{References}

1. Bharaj $P$, Wang YE, Dawes BE, Yun TE, Park $A$, Yen B, Basler CF, Freiberg AN, Lee B, Rajsbaum R . The Matrix Protein of Nipah Virus Targets the E3-Ubiquitin Ligase TRIM6 to Inhibit the IKKE Kinase-Mediated Type-I IFN Antiviral Response. PLoS Pathog. 2016; 12(9):e1005880.

2. Chua KB, Goh KJ, Wong KT, Kamarulzaman A, Tan PS, Ksiazek TG, Fatal encephalitis due to Nipah virus among pig-farmers in Malaysia. Lancet. 1999;354:1257-9.

https://www.ncbi.nlm.nih.gov/pubmed/1 0520635

3. Chua KB, Bellini WJ, Rota PA, Harcourt BH, Tamin A, Lam SK, et al. Nipah virus: A recently emergent deadly paramyxovirus. 
Rama Adiga, Journal of Biomedical and Pharmaceutical Research

Science 2000; 288, 1432-1435.

4. Chua KB, Koh CL, Hooi PS, Wee KF, Khong $\mathrm{JH}$, Chua BH, Chan YP, Lim ME, Lam SK.Isolation of Nipah virus from Malaysian Island flying-foxes. Microbes Infect. 2002;4 (2):145-51. https://www.ncbi.nlm.nih.gov pubmed/11880045

5. Chua KB, Chua BH, Wang CW. Anthropogenic deforestation, El Niño and the emergence of Nipah virus in Malaysia. Malays J Pathol. 2002;24:15-21.

6. Chadha MS, Comer JA, Lowe L, Rota PA, Rollin PE, Bellini WJ, Ksiazek TG, Mishra AC. Nipah Virus-associated Encephalitis Outbreak, Siliguri, India. Emerg. Infect. Dis. 2006;12:235. doi: 10.3201/eid1202.051247.

7. Ching PKG, Reyes VCDL, Sucaldito MN, Tayag E, Columna-Vingno AB, Malbas FF, Bolo GC, Sejvar JJ, Eagles D, Playford G. Outbreak of Henipavirus Infection, Philippines, 2014. Emerg. Infect. Dis. 2015; 21:328-331. doi:10.3201/eid2102.141433.

8. CDC. Outbreak of Hendra-like virus -Malaysia and Singapore, 1998-1999. MMWR 1999; 48:265-9.

9. Daszak $P$, Cunningham $A A$, Hyatt $A D$. Emerging infectious diseases of wildlifethreats to biodiversity and human health. Science. 2000; 287:443-449. doi: 10.1126/science.287.5452.443.

10. Goh KJ, Tan CT, Chew NK, Tan PS, Kamarulzaman A, Sarji SA, Clinical features of Nipah virus encephalitis among pig farmers in Malaysia. N Engl J Med. 2000; 342:1229-35. https://www.ncbi. nlm.nih.gov/pubmed/10781618

11. Gurley ES, Montgomery JM, Hossain MJ, Bell M, Azad AK, Islam MR, Molla MA, Carroll DS, Ksiazek TG, Rota PA, et al. Person-to-person transmission of Nipah virus in a Bangladeshi community.Emerg Infect Dis. 2007; 13(7):1031-7. https://www.ncbi.nlm.nih.gov/pmc/article s/PMC2878219/
12. Hayman DT, Suu-Ire $R$, Breed AC, McEachern JA, Wang $L$, et al. Evidence of henipavirus infection in West African fruit bats. PLoS One 2008; 3: e2739.

13. Hsu, VP, Hossain, MJ, Parashar UD et al. Nipah virus encephalitis reemergence, Bangladesh. Emerg. Infect. Dis.2004; 10 :2082-2087.

https://www.ncbi.nlm.nih.gov/pmc/article s/PMC3323384/

14. Harcourt $B H$, Lowe L, Tamin A, Liu $X$, Bankamp B, Bowden N, Rollin PE, Comer JA, Ksiazek TG, Hossain MJ et al.: Genetic characterization of Nipah virus, Bangladesh, 2004. Emerg Infect Dis 2005; 11:1594-1597

https://www.ncbi.nlm.nih.gov/pmc/article s/PMC3366751/

15. Eaton BT, Mackenzie JS, Wang LF .Henipaviruses. In: Knipe DM, Griffin DE, Lamb RA, Straus SE, Howley PM et al., editors. Fields Virology. Philadelphia: Lippincott Williams \& Wilkins.2007; pp. 1587-1600.

16. Kumar AKA \& Kumar ASA.Deadly Nipah Outbreak in Kerala: Lessons Learned for the Future.Indian J Crit Care Med. 2018 ; 22(7): 475-476.doi: 10.4103/ijccm.IJCCM_282_18

17. Lam SK, Chua KB (2002) Nipah virus encephalitis outbreak in Malaysia. Clin Infect Dis 34 Suppl 2: S48-51.

18. Lee KE, Umapathi T, Mmed CBT, Chua TS, Oh ML, Frcp KMF, Kurup A, Asha Das MD, Tan KY. The neurological manifestations of Nipah virus encephalitis, a novel paramyxovirus. Ann Neurol. 1999;46:428432. doi: 10.1002/1531-8249(199909)46: 3<428::AID-ANA23>3.0.CO;2-I.

19. Luby SP, Gurley ES, Hossain MJ. Transmission of human infection with Nipah virus. In: Institute of Medicine (US). Improving Food Safety through a One Health Approach: Workshop Summary. Washington (DC): National Academies Press (US), A11; 2012. 
Rama Adiga, Journal of Biomedical and Pharmaceutical Research

20. Martinez-Gil L, Vera-Velasco NM, Mingarro I. Exploring the human-Nipah virus protein-protein interactome. J. Virol. 2017; 91:e01461-01417. doi: 10.1128/ JVI.01461-17.

21. Montgomery JM, Hossain MJ, Gurley E, Carroll DS, Croisier A, Bertherat E, et al. Risk factors for Nipah virus encephalitis in Bangladesh. Emerg Infect Dis. 2008; 14(10):1526-32.

https://www.ncbi.nlm.nih.gov/pmc/article s/PMC2609878/

22. Nowak RM. Old World fruit bats: Pteropodidae (flying foxes). In: Nowak RM, editor. Walker's bats of the world. 5th ed. Baltimore: The Johns Hopkins University Press; 1994. p. 55-8.

23. Parashar UD, Sunn LM, Ong F, Mounts AW, Arif MT, Ksiazek TG, et al. Case-control study of risk factors for human infection with a new zoonotic paramyxovirus, Nipah virus, during a 1998-1999 outbreak of severe encephalitis in Malaysia. J Infect Dis. 2000;181:1755-9 10.1086/315457. https://www.ncbi.nlm.nih.gov/pubmed/1 0823779

24. Sherrini BA, Chong TT. Nipah encephalitis an update. Med J Malaysia. 2014;69 Suppl A:103-11.

25. Tan CT \& Tan KS. Nosocomial transmissibility of Nipah virus.J Infect Dis 2001; 184, 1367.

26. Uppal PK. Emergence of Nipah virus in Malaysia. Ann N Y Acad Sci 2000; 916: 354$357 . \quad$ https://www.ncbi.nlm.nih.gov/ pubmed/11193645

27. Wacharapluesadee $S$, Samseeneam $P$, Phermpool M, Kaewpom T, Rodpan A, Maneeorn $\mathrm{P}$, et al. Molecular characterization of Nipah virus from Pteropus hypomelanus in southern Thailand. Virol. J. 2016;13:53. doi: 10.1186/s12985-016-0510-x

28. Wang L, Harcourt BH, Yu M, Tamin A, Rota PA, Bellini WJ, Eaton BT. Molecular biology of Hendra and Nipah viruses. Microbes Infect.2001;3:279-287. doi:10.1016/S1286 $-4579(01) 01381-8$.

29. World Health Organization Nipah virus outbreaks in the WHO South-East Asia Region, Communicable Diseases Department, Disease Surveillance and Epidemiology. Update 1 May 2012 